St. Subaedah : Peranan Bahan Organik Chromolaena odorata dan Crotalaria juncea dalam Meningkatkan Ketersediaan Hara Fosfor bagi Pertumbuhan Tanaman Kedelai di Lahan Kering.

\title{
PERANAN BAHAN ORGANIK Chromolaena odorata DAN Crotalaria juncea DALAM MENINGKATKAN KETERSEDIAAN HARA FOSFOR BAGI PERTUMBUHAN TANAMAN KEDELAI DI LAHAN KERING
}

\author{
(The Role of Organic Material Chromolaena odorata and Crotalaria Juncea to \\ Increase Availability of Elements Phosphorus for the Growth of Soybean in the Dry \\ Land)
}

\author{
St. Subaedah* \\ *) Jurusan Agroteknologi Fakultas Pertanian UMI, Email:st.subaedah@umi.ac.id
}

\begin{abstract}
The development of soybean crops in dry land are often confronted with low soil fertility which causes be hampered growth and crop production. The efforts to manage soil fertility with application of fertilizer chemical also did not have much effect, because the soil buffering capacity is low which causes the fertilizer is given can be leached out or bound by other elements (especially elements $P$ ), so that $P$ can not be absorbed by plants, while $P$ is an element plants need in large quantities. This study aims to improve the availability of nutrients phosphate for renewed growth in soybean crops in dry land. This study aims to improve the availability of nutrients phosphate for renewed growth in soybean crops in dry land. This study was designed with a completely randomized design, factorial of two factors. The first factor is the kind of organic material consisting of four levels ie: without any organic material, organic material from plants Chromolaena odorata, organic material from plants Crotalaria juncea and organic matter from manure. The second factor is P fertilization that consists of two levels, namely: $50 \mathrm{~kg}-36 . \mathrm{ha}$ $S P-1$ and SP-36.ha $100 \mathrm{~kg}-1$. The results showed that the organic matter C. odorata and $C$. juncea with $P$ fertilization can improve nutrient availability in the soil $P, P$ nutrient uptake by soybean plants also increased with organic matter $C$. odorata and $C$. juncea accompanied fertilization $P$.
\end{abstract}

Keywords: soybean, growth, organic matter, and phosphorus

\section{PENDAHULUAN}

Impor kedelai dari tahun ke tahun terus mengalami peningkatan, hal ini terjadi karena permintaan kedelai terus meningkat sementara produksi kedelai masih sangat rendah. Pemacuan peningkatan produksi kedelai di dalam negeri telah banyak diupayakan oleh petani, diantaranya dengan pengelolaan kesuburan tanah, seperti penggunaan pupuk an-organik. Namun demikian karena pengembangan tanaman kedelai umumnya di lahan kering, penggunaan pupuk an-organik sering tidak efektif (khususnya pupuk fosfat). Hal ini dikarenakan lahan kering didominasi oleh tanah yang masam dan kadar bahan organik yang rendah, yang menyebabkan terjadinya fiksasi $\mathrm{P}$ oleh $\mathrm{Al}$ atau $\mathrm{Fe}$, sehingga fosfor menjadi tidak tersedia bagi tanaman (Matsumoto, 2000). 
St. Subaedah : Peranan Bahan Organik Chromolaena odorata dan Crotalaria juncea dalam Meningkatkan Ketersediaan Hara Fosfor bagi Pertumbuhan Tanaman Kedelai di Lahan Kering.

Sementara unsur $\mathrm{P}$ termasuk salah satu unsur yang diperlukan tanaman dalam jumlah besar. Pada tanaman kedelai, unsur $\mathrm{P}$ merupakan penyusun lesitin yang memegan peranan penting dalan integritas membran (Gardner, Pearce dan Mitchell, 1991). Oleh karena itu diperlukan upaya untuk memperbaiki ketersediaan unsur P, misalnya dengan penggunaan bahan organik.

Bahan organik meningkatkan pergerakan $\mathrm{P}$ dan kadar $\mathrm{P}$ dalam larutan tanah. Dekomposisi bahan organik menghasilkan asam-asam organik antara lain asam humat dan asam fulvat. Asam humat dan asam fulfat banyak mengikat kation-kation polivalen seperti $\mathrm{Ca}^{++}, \mathrm{Fe}^{++}$ dan $\mathrm{Al}^{+++}$membentuk kelat $\mathrm{Ca}, \mathrm{Fe}$ dan $\mathrm{Al}$ (Ahmad dan Tan, 1991) sehingga P dilepas ke dalam larutan tanah dan akhirnya dapat diserap oleh tanaman yang akan memperbaiki pertumbuhan dan produksi tanaman.

Bahan organik dihasilkan oleh tumbuhan melalui proses fotosintesis, sehingga unsur $\mathrm{C}$ merupakan penyusun utama dari bahan organik tersebut yang berada dalam bentuk senyawa-senyawa polisakarida (Sugito. Nuraeni dan
Nihayati. 1995). Bahan organik merupakan salah satu komponen yang sangat penting bagi ekosistem tanah. karena merupakan sumber dan pengikat hara. juga sebagai substrat bagi mikroba tanah (Syekfani. 1998).

Penambahan bahan organik ke dalam tanah akan meningkatkan kandungan bahan organik yang akan memperbaiki kesuburan tanah. Bahan organik merupakan kunci kesuburan tanah karena memperbesar kemampuan tanah mengikat hara, dengan demikian meningkatkan kemampuan tanah menyediakan hara untuk tanaman, mengurangi pencucian hara, menambah kemampuan tanah menahan air, sehingga ketersediaan air tanah meningkat dan kemantapan struktur tanah serta sebagai sumber energi bagi biota tanah (Samosir, 1997).

Berbagai jenis sumber bahan organik yang dapat diberikan untuk meperbaiki kesuburan tanah, seperti bahan organik yang berasal dari kotoran ternak (pupuk kandang), ataukan dari limbah pertanaman, atau tumbuh-tumbuhan liar yang tumbuh di sekitar pertanaman. Daerah-daerah terbuka banyak dijmosir umpai tumbuhan liar Chromolaena 
St. Subaedah : Peranan Bahan Organik Chromolaena odorata dan Crotalaria juncea dalam Meningkatkan Ketersediaan Hara Fosfor bagi Pertumbuhan Tanaman Kedelai di Lahan Kering.

odorata dan Crotalaria juncea. Kedua jenis tumbuhan ini berpotensi untuk dijadikan sumber bahan organik yangdapat memperbaiki kesuburan tanah. Hasil penelitian Suntoro et al., (2001) menunjukkan bahwa penggunaan pangkasan Chromolaena odorata berkorelasi positif terhadap peningkatan ketersediaan hara $\mathrm{P}$ dan berkorelasi negatif dengan kadar Al-dd tanah. Demikian pula hasil penelitian Subaedah et al., (2004; 2016) menunjukkan bahwa penggunaan Crotalaria juncea sebagai mulsa organik mampu meningkatkan ketersediaan hara $\mathrm{P}$ lebih tinggi dibanding tanpa penggunaan bahan organik.

Berdasarkan fenomena tersebut maka dilakukan penelitian untuk mengetahui potensi dari bahan organik Chromolaena odorata dan Crotalaria juncea dalam meningkatkan ketersediaan hara fosfor bagi tanaman kedelai.

\section{METODE PENELITIAN}

Percobaan ini didesain dengan Rancangan Acak Lengkap pola faktorial dua faktor. Faktor I adalah macam bahan organik yang terdiri dari empat taraf yaitu: B0 : tanpa bahan organik
B1 : bahan organik dari tanaman Chromolaena odorata

B2 : bahan organik dari tanaman Crotalaria juncea

B3 : bahan organik dari pupuk kandang

Faktor kedua adalah pemupukan $\mathrm{P}$

anorganik yang terdiri dari dua taraf yaitu:

$\mathrm{P} 1=50 \mathrm{~kg} \mathrm{SP}-36 . \mathrm{ha}^{-1}$

$\mathrm{P} 2=100 \mathrm{~kg} \mathrm{SP}-36 \cdot \mathrm{ha}^{-1}$

Dari kedua faktor diperoleh 8 kombinasi perlakuan dan diulang sebanyak tiga kali sehingga diperoleh 24 unit satuan percobaan.

\section{Pelaksanaan Percobaan}

Percobaan dilakukan di rumah kaca Fakultas Pertanian UMI. Bahan pangkasan Chromolaena odorata dan Crotalaria juncea dipotong-potong dengan ukuran $\pm 2 \mathrm{~cm}$, setelah itu bahan organik dicampur dengan $10 \mathrm{~kg}$ tanah top soil demikian juga dengan pupuk kandang, kemudian dimasukkan dalam pot yang berukuran tinggi $30 \mathrm{~cm}$ dan diameter $30 \mathrm{~cm}$. Dosis bahan organik yang digunakan setara dengan 10 ton.ha ${ }^{-1}$. Penanaman kedelai dilakukan sebanyak 5 biji tiap pot kemudian disisakan 2 tanaman setelah tanaman berumur 2 minggu. Pemupukan SP-36 dilakukan 
St. Subaedah : Peranan Bahan Organik Chromolaena odorata dan Crotalaria juncea dalam Meningkatkan Ketersediaan Hara Fosfor bagi Pertumbuhan Tanaman Kedelai di Lahan Kering.

segera setelah tanam dengan dosis sesuai dengan ketentuan perlakuan. Pemeliharaan tanaman meliputi pemupukan urea dan $\mathrm{KCl}$ dilakukan pada saat tanam, Penyiraman dilakukan untuk mempertahankan kelembaban tanah.

\section{Pengamatan}

Adapun peubah yang diamati dalam percobaan ini adalah :

1. Analisis kandungan P-tanah tersedia (Bray-II) yang dilakukan pada saat satu dan dua bulan setelah tanam

2. Analisis serapan hara $\mathbf{P}$ oleh tanaman kedelai pada umur 2 bulan yang ditetapkan dengan destruksi basah menggunakan $\mathrm{HNO}_{3} \quad 65 \%$ dan $\mathrm{HClO}_{4} 70 \%$ (Puslittanak, 1998)

3. Analisis pertumbuhan tanaman yang mencakup laju tumbuh relatif (LTR) yang diamati pada umur 2, 4, 6 dan 8 minggu setelah tanam.

$$
\mathrm{LTR}=\frac{\mathrm{Ln} \mathrm{W}_{2}-\mathrm{Ln} \mathrm{W}_{1}}{\mathrm{~T} 2-\mathrm{T} 1}
$$

Dimana:

$\mathrm{W} 2$ = bobot kering total tanaman pada pengamatan kedua

$\mathrm{W} 1$ = bobot kering total tanaman pada pengamatan pertama

$\mathrm{T} 1, \mathrm{~T} 2=$ masing-masing adalah waktu pengamatan pertama dan kedua (minggu).
4. Bobot biomass (kering oven dengan suhu $60^{\circ} \mathrm{C}$ selama 48 jam) tanaman kedelai untuk tajuk dan akar pada umur 4 dan 8 MST.

\section{HASIL DAN PEMBAHASAN}

\section{Kadar Hara P Tanah Tersedia}

Hasil analisis kadar P tanah tersedia yang disajikan pada Gambar 1a dan 1b menunjukkan bahwa kadar P tersedia dari tanah lebih tinggi yaitu antara 12,5513,33 ppm dengan pemberian berbagai jenis bahan organik dibandingkan tanpa pemberian bahan organik dengan kadar $\mathrm{P}$ tersedia sebesar 12,23-12,44 ppm. Pada periode pengamatan 4 MST (Gambar 1a) menunjukkan bahwa perlakuan bahan organik dan interaksinya dengan pemupukan fosfor $100 \mathrm{~kg}$ P2O5/ha diperoleh kandungan hara $\mathrm{P}$ tanah tersedia yang lebih tinggi atau meningkat 2,25\% dibandingkan atau dengan pemupukan fosfor $50 \mathrm{~kg} \mathrm{P} 2 \mathrm{O} 5 / \mathrm{ha}$.

Gambar 1b menunjukkan pola yang sama dengan Gambar 1 yang juga menunjukkan peningkatan kadar hara $\mathrm{P}$ tanah tersedia mencapai $3,66 \%$ pada periode pengamatan 8 MST. Hasil penelitian ini sejalan dengan penelitian yang dilakukan Jamil, et al. (2008) dan 
St. Subaedah : Peranan Bahan Organik Chromolaena odorata dan Crotalaria juncea dalam Meningkatkan Ketersediaan Hara Fosfor bagi Pertumbuhan Tanaman Kedelai di Lahan Kering.

penelitian yang dilakukan Sugiyanto dan Baon (2008) yang menyimpulkan bahwa penggunaan pupuk fosfor dan pupuk fosfor tersedia.
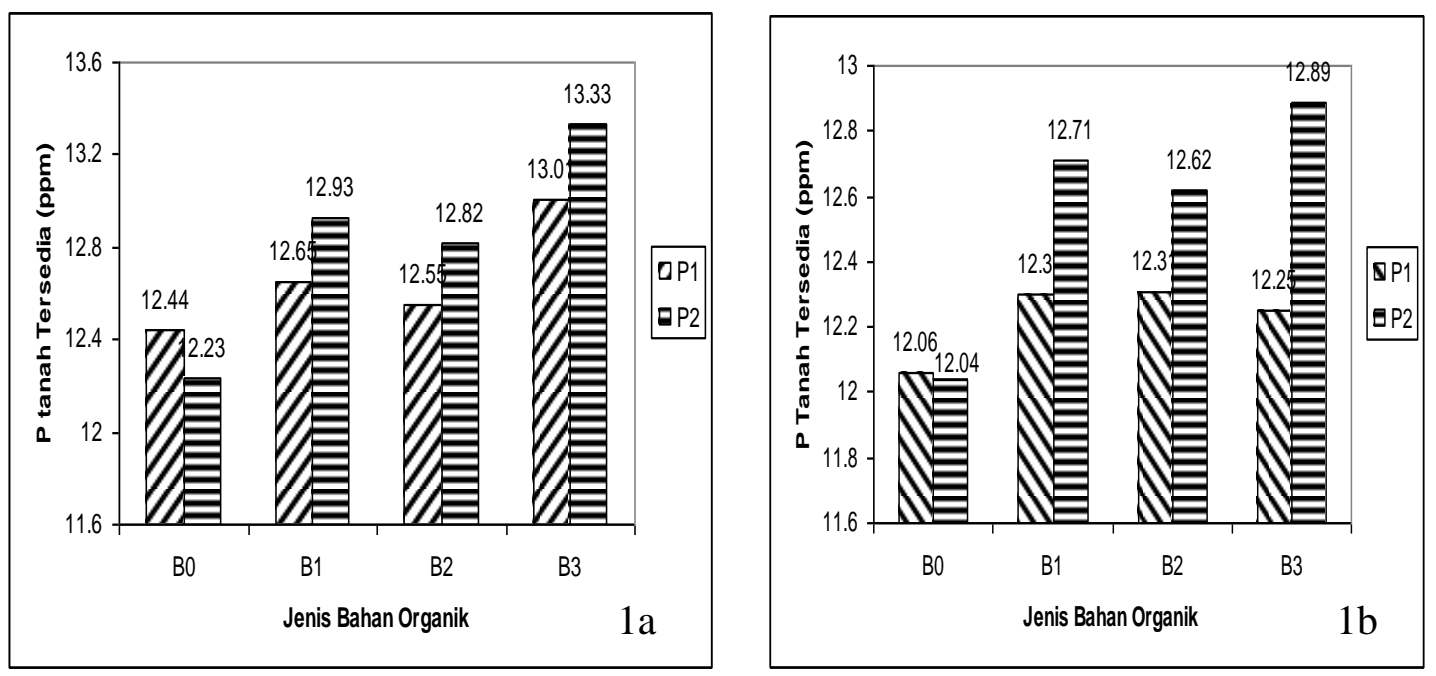

Gambar 1a dan 1 b. Pengaruh Jenis Bahan Organik dan Pemupukan Fosfor Terhadap Kadar P Tanah Tersedia pada Periode 4 dan 8 MS

Keterangan: $\mathrm{B} 0=$ tanpa bahan organik, $\mathrm{B} 1=\mathrm{BO}$ Chromalaena odorata $\mathrm{B} 2=\mathrm{BO}$ Crotalaria juncea $\mathrm{B} 3=\mathrm{BO}$ Pupuk Kandang Sapi (Keterangan ini berlaku untuk seterusnya)

Adanya peningkatan unsur $\mathrm{P}$ ini sumber pupuk $\mathrm{P}$ yang diberikan. akibat penambahan bahan organik. Menurut Tisdale, et al., (1985),

Dekomposisi bahan organik akan peningkatan konsentrasi $\mathrm{P}$ tersedia dalam menyebabkan unsur $\mathrm{P}$ tanah yang ada tanah kemungkinan besar disebabkan dalam tanah menjadi tersedia karena beberapa hal seperti peningkatan kelarutan aktivitas mikroorganisme dan tanaman pupuk kimia dan pelarutan $\mathrm{PO}_{4}$ dari melalui eksudat yang dihasilkan oleh kompleks tidak larut dengan Fe, Al, Ca, akar-akaranya. Di samping itu pengaruh dll karena asam humik yang dapat asam-asam organik yang dihasilkan dari dihasilkan selama pelapukan bahan pelapukan tumbuhan liar dapat organik menyebabkan ketersediaan unsut $P$ bertambah dan juga dapat berasal dari 
St. Subaedah : Peranan Bahan Organik Chromolaena odorata dan Crotalaria juncea dalam Meningkatkan Ketersediaan Hara Fosfor bagi Pertumbuhan Tanaman Kedelai di Lahan Kering.

Serapan Hara P oleh Tanaman Kedelai

Analisis serapan hara $\mathrm{P}$ oleh tanaman kedelai disajikan pada Gambar 3 dan Gambar 4 yang menunjukkan bahwa analisis serapan hara $\mathrm{P}$ meningkat dengan pemberian berbagai jenis bahan organik dibandingkan tanpa pemberian bahan organik, yang diperlihatkan dengan meningkatnya kadar $\mathrm{P}$ dalam jaringan tanaman kedelai sebesar 16-18\% dibandingkan dengan perlakuan tanpa pemberian bahan organik. Peningkatan serapan hara $\mathrm{P}$ oleh tanaman kedelai lebih terlihat lagi dengan peningkatan dosis pupuk $\mathrm{P}$ yang diberikan.
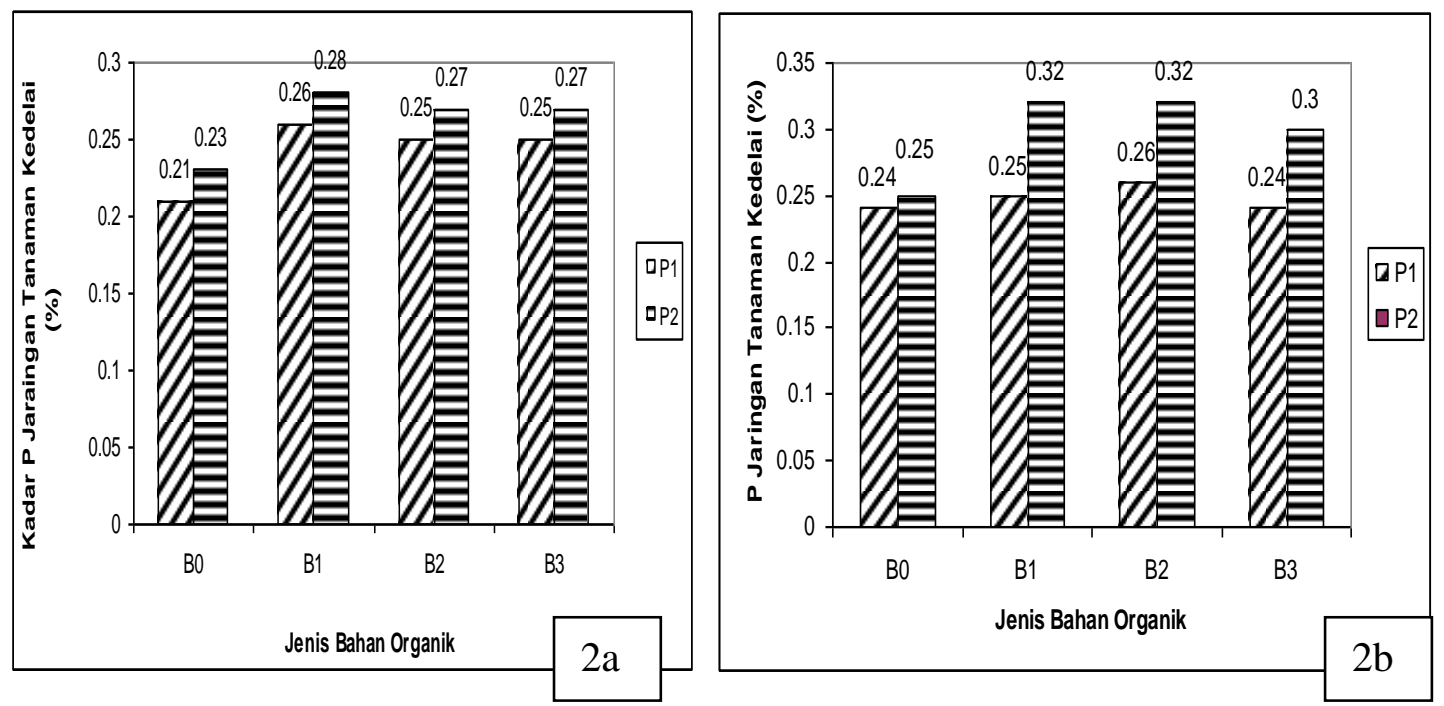

Gambar 2a dan 2b. Pengaruh Jenis Bahan Organik dan Pemupukan Fosfor Terhadap Kadar P jaringan Tanaman Kedelai Umur 4 dan 8 MST

Pada periode pengamatan 4 dan 8 MST (Gambar 2a dan 2b) menunjukkan bahwa perlakuan bahan organik dan interaksinya dengan pemupukan fosfor 50 $\mathrm{kg}$ P2O5/ha (P1) diperoleh kandungan hara $\mathrm{P}$ dalam jaringan tanaman yang lebih tinggi dibandingkan dengan pemupukan fosfor $100 \mathrm{~kg}$ P2O5/ha (P2).
Meningkatnya kadar $\mathrm{P}$ jaringan dengan meningkatnya dosis pemupukan $\mathrm{P}$ sejalan dengan meningkatnya kadar $\mathrm{P}$ tanah tersedia pada periode yang sama.

Gambar 2a juga menunjukkan bahwa pada periode pengamatan 4 MST pemanfaatan bahan organik dari tumbuhan liar (B1 dan B2) diperoleh kadar $\mathrm{P}$ jaringan tanaman kedelei yang relatif 
St. Subaedah : Peranan Bahan Organik Chromolaena odorata dan Crotalaria juncea dalam Meningkatkan Ketersediaan Hara Fosfor bagi Pertumbuhan Tanaman Kedelai di Lahan Kering.

sama $(0,25-0,28 \%)$ dengan kadar $P$ jaringan tanaman kedelai dengan perlakuan bahan organik dari pupuk kandang yaitu $0,25-0,27 \%$. Namun demikian pada Gambar $2 b$ atau pada periode pengamatan 8 MST diperoleh kadar $\mathrm{P}$ jaringan tanaman kedelei yang lebih tinggi $(0,25-0,32 \%)$ pada pemanfaatan bahan organik dari tanaman Chromolaena dan Crotalaria sementara pada perlakuan bahan organik dari pupuk kandang diperoleh kadar $\mathrm{P}$ jaringan tanaman kedelei 0,24-0,3\%.

\section{Pengaruh Bahan Organik dan Pemupukan Fosfor \\ a. Laju Tumbuh Relatif (LTR) Tanaman Kedelai}

Analisis laju tumbuh relatif tanaman kedelai yang diamati pada penelitian ini mulai pada periode diberikan.

pengamatan 2, 4, 6 dan 8 MST.
Hasil perhitungan LTR tanaman kedelai menunjukkan bahwa pemanfaatan bahan organik tidak memperlihatkan adanya pengaruh yang nyata untuk periode pengamatan 2-4 MST dan 4-6 MST serta periode pengamatan 6-8 MST. Namun demikian dari hasil analisis nilai rata-rata LTR pada Gambar 5 terlihat bahwa penggunaan bahan organik diperoleh nilai LTR yang lebih pesat yaitu antara $0,676 \quad-\quad 0,802 \quad \mathrm{~g} \cdot \mathrm{g}^{-1} \cdot \mathrm{mgg}^{-1}$, sementara pada perlakuan tanpa bahan organik mempunyai nilai LTR antara $0,578-0,622 \mathrm{~g} \cdot \mathrm{g}^{-1} \cdot \mathrm{mgg}^{-1}$. Dari Gambar 5 juga menunjukkan bahwa perlakuan bahan organik Chromolaena dan pupuk kandang serta tanpa penggunaan bahan organik menunjukkan pola yang sama dimana terjadi peningkatan LTR dengan meningkatnya dosis pupuk fosfor yang 

St. Subaedah : Peranan Bahan Organik Chromolaena odorata dan Crotalaria juncea dalam Meningkatkan Ketersediaan Hara Fosfor bagi Pertumbuhan Tanaman Kedelai di Lahan Kering.
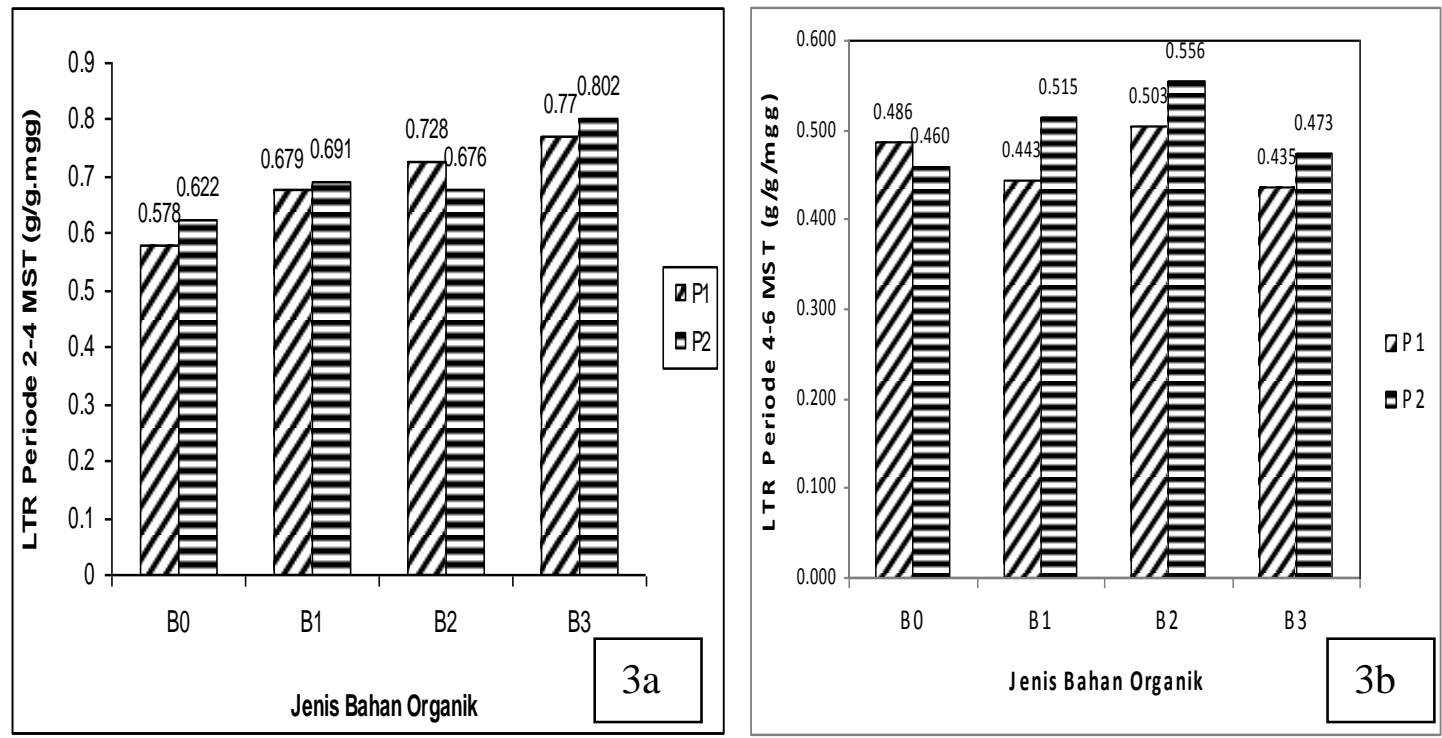

Gambar 3a dan 3b. Pengaruh Jenis Bahan Organik dan Pemupukan Fosfor Terhadap Laju Tumbuh Relatif Tanaman Kedelai pada Periode 2-4 MST dan Periode 4-6 MST

Analisis LTR yang hasilnya disajikan pada Gambar 3a menunjukkan bahwa terjadi perbedaan pola laju tumbuh tanaman kedelai antara tanaman kedelai yang diberi bahan organik dengan tanaman kedelai yang tidak diberi bahan organik. Pada tanaman kedelai yang diberi bahan organik (Chromolaena, Crotalaria dan pupuk kandang) terlihat bahwa nilai LTR lebih tinggi dengan meningkatnya dosis pupuk $\mathrm{P}$ yang diberikan. Gambar 3a juga menunjukkan bahwa penggunaan tumbuhan liar Crotalaria diperoleh nilai LTR yang lebih tinggi yaitu antara $0,503-0,556 \mathrm{~g} \cdot \mathrm{g}^{-1} \cdot \mathrm{mgg}^{-}$ ${ }^{1}$, sementara pada pemberian bahan organik dari pupuk kandang hanya menghasilkan nilai LTR antara 0,435$0,473 \mathrm{~g} \cdot \mathrm{g}^{-1} \cdot \mathrm{mgg}^{-1}$.

Laju tumbuh relatif periode 6-8 MST menunjukkan bahwa pemberian bahan organik dan pemupukan fosfor nyata mempengaruhi laju pertumbuhanan tanaman. Hasil uji lanjutan nilai LTR periode 6-8 MST pada Tabel 2 menunjukkan bahwa tanaman kedelai yang diberi perlakuan bahan organik baik dari jenis tumbuhan liar maupun dari pupuk kandang menunjukkan LTR yang yang lebih tinggi yaitu 0,236-0,269 g.g${ }^{1} \mathrm{mgg}^{-1}$ ddan berbeda nyata dengan perlakuan tanpa pemberian bahan organik 
St. Subaedah : Peranan Bahan Organik Chromolaena odorata dan Crotalaria juncea dalam Meningkatkan Ketersediaan Hara Fosfor bagi Pertumbuhan Tanaman Kedelai di Lahan Kering.

yang hanya mempunyai laju tumbuh 0,122 nyata diperoleh nilai LTR yang lebih g.g $\mathrm{g}^{-1} \mathrm{mg}^{-1}$. Sedang pada perlakuan tinggi yaitu $0,249 \quad \mathrm{~g} \cdot \mathrm{g}^{-1} \mathrm{mgg}^{-1}$ pemupukan fosfor terlihat bahwa dibandingkan dengan pemupukan fosfor

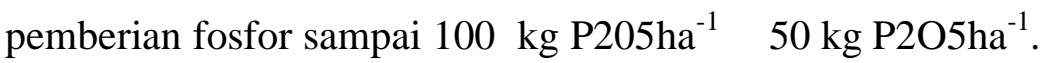

Tabel 2. Pengaruh Pemanfaatan Berbagai Jenis Bahan Organik dan Pemupukan Fosfor Terhadap LTR Tanaman Kedelai Pada Periode 6-8 MST

\begin{tabular}{|l|c|c|c|c|}
\hline \multirow{2}{*}{$\begin{array}{c}\text { Jenis Bahan } \\
\text { Organik }\end{array}$} & \multicolumn{2}{|c|}{ Pemupukan Fosfor } & Rata-rata & $\begin{array}{c}\text { NPBNT } \\
(\mathbf{0 , 0 5})\end{array}$ \\
\cline { 2 - 3 } $\begin{array}{l}\text { Tanpa Bahan } \\
\text { Organik }\end{array}$ & 0,130 & 0,114 & $0,122 \mathrm{~b}$ & $\mathbf{0 , 1 1 3}$ \\
BO Chromolaena & 0,231 & 0.306 & $0,269 \mathrm{a}$ & \\
BO Crotalaria & 0,219 & 0,286 & $0,253 \mathrm{a}$ & \\
Pupuk Kandang & 0,182 & 0,290 & $0,236 \mathrm{a}$ & \\
Rata-rata & $0,191 \mathrm{~b}$ & $0,249 \mathrm{a}$ & & \\
NPBNT (0,05) & $\mathbf{0 , 0 8}$ & & & \\
\hline
\end{tabular}

Keterangan: Angka yang diikuti oleh huruf yang sama pada baris dan kolom yang sama tidak berbeda nyata berdasarkan uji BNT pada taraf $5 \%$.

\section{b. Biomass Tanaman Kedelai}

Pengamatan biomassa tanaman yang didasarkan pada bobot kering oven total tanaman (disertai akar yang terangkut) pada umur 4 MST menunjukkan bahwa pemanfaatan bahan organik dan pemupukan fosfor serta interaksi antara keduanya nyata pengaruhnya dengan bobot kering terberat 0,770 g.tan- ${ }^{1}$ diperoleh pada interaksi antara pemanfaatan bahan organik pupuk kandang dengan pemupukan fosfor $50 \mathrm{~kg}$ P2O5 ha ${ }^{-1}$ (B3P1) dan tidak berbeda nyata dengan pemanfaatan bahan organik dari Crotalaria juncea dan Chromolaena odorata dengan bobot kering tanaman antara 0,607- 0.703 g.tan- ${ }^{1}$ ( Tabel 3). 
St. Subaedah : Peranan Bahan Organik Chromolaena odorata dan Crotalaria juncea dalam Meningkatkan Ketersediaan Hara Fosfor bagi Pertumbuhan Tanaman Kedelai di Lahan Kering.

Tabel 3. Pengaruh Pemanfaatan Berbagai Jenis Bahan Organik dan Pemupukan Fosfor Terhadap Biomass Tanaman Kedelai Pada Umur 4 MST

\begin{tabular}{|l|c|c|c|}
\hline \multirow{2}{*}{$\begin{array}{c}\text { Jenis Bahan } \\
\text { Organik }\end{array}$} & \multicolumn{2}{|c|}{ Pemupukan Fosfor } & \multirow{2}{*}{$\begin{array}{c}\text { NPBNT } \\
0,05\end{array}$} \\
\cline { 2 - 3 } & $\boldsymbol{P 1}$ & $\boldsymbol{P 2}$ & \multirow{2}{*}{0,100} \\
$\begin{array}{l}\text { Tanpa Bahan } \\
\text { Organik }\end{array}$ & $0,460^{\mathrm{b}}{ }_{\mathrm{z}}$ & $0,663^{\mathrm{a}}{ }_{\mathrm{y}}$ & \\
BO Chromolaena & $0,597^{\mathrm{b}} \mathrm{y}$ & $0.703^{\mathrm{a}} \mathrm{x}$ & \\
BO Crotalaria & $0,670^{\mathrm{a}} \mathrm{x}$ & $0,607^{\mathrm{a}} \mathrm{x}$ & \\
Pupuk Kandang & $0,770^{\mathrm{a}}{ }_{\mathrm{x}}$ & $0,707^{\mathrm{a}} \mathrm{x}$ & \\
\hline
\end{tabular}

Keterangan : angka yang diikuti oleh huruf yang sama pada baris $(\mathrm{a}, \mathrm{b})$ dan pada kolom $(\mathrm{x}, \mathrm{y})$ tidak berbeda nyata berdasarkan uji BNT

Pengaruh baik dari pemanfaatan organik meningkatkan pergerakan $\mathrm{P}$ dan bahan organik terhadap pertumbuhan kadar $\mathrm{P}$ dalam larutan tanah. tanaman kedelai yang diperlihatkan oleh Dekomposisi bahan organik menghasilkan LTR yang lebih pesat serta biomas asam-asam organik antara lain asam tanaman yang lebih berat, disebabkan humat dan asam fulvat. Asam humat dan adanya perbaikan ketersediaan hara $\mathrm{P}$ asam fulfat banyak mengikat kationyang makin meningkat dengan kation polivalen seperti $\mathrm{Ca}^{++}, \mathrm{Fe}^{++}$dan pemanfaatan bahan organik dibandingkan $\mathrm{Al}^{+++}$membentuk kelat $\mathrm{Ca}, \mathrm{Fe}$ dan $\mathrm{Al}$ dengan tanpa bahan organik (Gambar 3 (Ahmad dan Tan, 1991) sehingga $P$ dan 4). Peningkatan kadar $P$ tanah ini dilepas ke dalam larutan tanah dan sangat berarti bagi pertanian lahan kering akhirnya dapat diserap oleh tanaman yang mengingat masalah pokok dalam akan memperbaiki pertumbuhan dan pengelolaan lahan kering sebagai produksi tanaman.

sumberdaya pertanian adalah masalah ketersediaan unsur $P$ yang sering membatasi pertumbuhan tanaman. Bahan 
St. Subaedah : Peranan Bahan Organik Chromolaena odorata dan Crotalaria juncea dalam Meningkatkan Ketersediaan Hara Fosfor bagi Pertumbuhan Tanaman Kedelai di Lahan Kering.

\section{KESIMPULAN}

1. Pemanfaatan bahan organik Chromolaena odorata dan Crotalaria

2. juncea disertai pemupukan $\mathrm{P}$ mampu meningkatkan ketersediaan hara $\mathrm{P}$ dalam tanah.

3. Serapan hara $\mathrm{P}$ oleh tanaman kedelai meningkat dengan pemberian bahan organik Chromolaena odorata dan Crotalaria juncea disertai pemupukan $\mathrm{P}$

4. Peningkatan ketersediaan hara $\mathrm{P}$ tanah dan serapan hara $\mathrm{P}$ oleh tanaman kedelai juga meningkatkan laju tumbuh relatif tanaman dan biomass tanaman kedelai.

\section{DAFTAR PUSTAKA}

Ahmad, F., and K.H. Tan. 1991. Availability of fixed phosphate to corn (Zea mays L.) seedling as affected by humic acids. Indon.J.Trop.Agric. 2(2):66-72.

Gardner, F.P. , R.B. Pearce and R.L. Mitchell. 1991. Fisiologi Tanaman Budidaya (Terjemahan H. Susilo). Universitas Indonesia (UI-Press). 426p.

Jamil, D. Harahap, Siti Maryam, dan M. P.Yufdy . 2008. Reklamasi lahan sawah tadah hujan dengan pupuk fosfor dan bahan organik di Sumatra Utara. BPTP Sumatera Utara.
Matsumoto, H. 2000. Cell biology of aluminium toxicity and tolerance in higher plants. Int. Rev. Cytol. 2000:1-46.

Puslittanak. 1998. Penuntun Analisis Kimia Tanah dan Tanaman. Staf Lab. Kimia. Puslittanak, Bogor.

Sitompul, S.M., dan B. Guritno. 1995. Analisis Pertumbuhan Tanaman. Gadjah Mada University Press. 412p.

Situmorang, R. 1999. Pemanfaatan bahan organic setempat, Mucuna, $\mathrm{Sp}$ dan fosfat alam untuk memperbaiki sifat-sifat tanah Palehumults di Miramontana, Sukabumi. Disertasi, IPB. Bogor.

Subaedah, St.; A.Aladin; Nirwana. 2016. Fertilization of Nitrogen, Phosphor and Application of Green Manure of Crotalaria Juncea in Increasing Yield of Maize in Marginal Dry Land. Agriculture and Agricultural Science Procedia, 9 (2016):20-25.

Subaedah, St., B. Guritno, Syamsulbahri, dan A.Sastrosupadi. 2004. Respon Tanaman Jagung dan Perbaikan Sifat Kimia Tanah pada Beberagai Jenis Tanaman Penutup di Lahan Kering. Agrivita 26 (3): 222-226.

Sugito, Y., Y. Nuraini dan E. Nihayati. 1995. Sistem Pertanian Organik. Fakultas Pertanian Universitas Brawijaya, Malang. 84p. 
St. Subaedah : Peranan Bahan Organik Chromolaena odorata dan Crotalaria juncea dalam Meningkatkan Ketersediaan Hara Fosfor bagi Pertumbuhan Tanaman Kedelai di Lahan Kering.

Sugiyanto dan Baon, J.B. 2008.

Ketersediaan fosfat asal tanah dan fosfat alam akibat sumber bahan organik yang berbeda. Pelita Perkebunan, 24(2):114-127

Suntoro, Syekhfani, E.Handayanto dan Sumarno. 2001. Penggunaan bahan pangkasan Krinyu (Chromolaena odorata) dan Gamal (Gliricidia sepium) untuk meningkatkan ketersediaan $\mathrm{P}, \mathrm{K}, \mathrm{Ca}$ dan $\mathrm{Mg}$ pada Oxic Dystrundept di Jumapolo, Karanganyar, Jawa Tengah. Agrivita 23 (1): 10-23.

Syekhfani. 1997. Hara-Air TanahTanaman. Jurusan Tanah Fakultas Pertanian Universitas.

Tisdale, S. L., and W.L. Nelson. 1975. Soil Fertility and Fertilizers. Third Edition. Collier Mac Millan International Editions. 694p. 